\title{
EUROJUST Joint Investigation Teams (JIT)
}

\author{
Myzafer Elezi \\ Lecturer, Department of Justice, Ismail Qemali University of Vlora \\ E-mail: elezi_myzafer@yahoo.com
}

Adv. Neshet Ngucaj

Chamber of Advocates-Vlore

E-mail: n.ngucaj_av@hotmail.com

\section{Doi:10.5901/mjss.2014.v5n1p103}

\begin{abstract}
The title of this paper identifies key words starting with police and judicial cooperation, to proceed with European level agencies responsible for this cooperation, and Eurojust Euopol, respectively, and further with the new mechanism of this cooperation, the Joint Teams investigation. While it is true that this cooperation has its origins in Title VI, under the third pillar of the Treaty on European Union signed on 7 February 1992 in Maastricht, the successive developments at European and international treaty for the European Union underwent significant changes, and so changed the provisions relating to judicial and police cooperation, the Treaty of Amsterdam and the Treaty of Nice to achieve the changes brought by the Lisbon Treaty (Treaty on the Functioning of the European Union).Precisely, the evolution of judicial and police cooperation, is the starting point of this paper, because through a brief overview, the judicial and police cooperation, can be identified, mechanisms and agencies of the European Union, created specifically for this purpose, especially Europol and Eurojust..
\end{abstract}

Keywords: Eurojust, the judicial cooperation, the joint investigation team, judicial assistance, cross-border criminal cases;

\section{Introduction}

Eurojust's mission, to promote coordination, practically is realized within a legal regime in the field of criminal cooperation, which is continuously developed since the Treaty on European Union set the EU competence in this field. Convention on Mutual Legal Assistance of 2000 is the cornerstone of this regime. Convention on Mutual Legal Assistance in 2000, is a new EU mechanism for judicial assistance requests, it contains detailed rules for sending documents, tracking of requests for mutual legal assistance, exchange of information, transfer of persons convicted for the purpose of investigation, undercover operations and telecommunications interception. The concept of Joint Investigation Teams also presented to the Convention on Mutual Legal Assistance in 2000. Convention in 2000 is the document that defines the main roads, to seek and provide mutual legal assistance in criminal cases within the EU border. Article 10 (2) of the 2000 Protocol to the Convention provides intermediary role of Eurojust in cases where the competent authorities face problems in executing requests. It should be remembered slow process of ratifying the Convention in 2000.

During this process, Eurojust made many times call for its ratification in order to apply the instrument ${ }^{1}$. The importance of the Convention 2000, related to its application in cross-border criminal cases. However, after more than 10 years of its ratification, not all member states have ratified the Convention as a whole, and this leads to problems in its implementation. Eurojust has reported problems with the use of surveillance, return stolen items, the creation of Joint Investigation Teams. ${ }^{2}$ Eurojust in its annual reports often noted, when has requested to provide assistance in connection with the difficulties faced by national authorities in the implementation of the Convention 2000. In 2009 and 2010 reports of Eurojust made a detailed analysis of the problems that arise where the involvement of Eurojust can promote cooperation, facilitate the exchange of information or the issuance of rogatory letters in emergencies. Eurojust also assists national authorities in clarifying the relationship between the legal provisions of the EU and national. However, there are some moments where legal gaps should be filled and Eurojust can help to encourage, but the legislator to

${ }_{1}^{1}$ Raportet Vjetore të Eurojust 2002-2005

${ }^{2}$ Raportet Vjetore të Eurojust 
resolve the issue. In 2011, 33 were created, Joint Investigation Teams with the assistance of Eurojust. Prosecutors, judges and police officers to Eurojust participated in 29 of the Joint Investigation Teams in accordance with Article $9 / \mathrm{f}$ Eurojust Decision. Two third countries had participating in multilateral teams, supported by Eurojust. The growing number of Joint Investigation Teams, created with the assistance and participation of Eurojust, shows that national authorities are increasingly realize the importance of this instrument, and use more and more in their operational work.

\section{The Legal Basis of Eurojust Participation in Joint Investigation Teams}

Eurojust provides support to joint investigation teams, provided, as in national legislation, and the legislation's Eurojust.

\subsection{National legislation}

National legislation may serve as a basis for support, which gives Eurojust JIT, when determining the Member State competence. If the domestic law, leaves in place the authority of a member's national prosecutor, the member may participate as national prosecutor. Also in accordance with Article 1 (12) of the Framework Decision, national law may provide that different persons the representatives of the competent authorities of the Member States to create the team participate in team activities. Thus, these members may also be representatives of Eurojust. The legislation of some Member States specifically mentioned the inclusion of Eurojust. For example, Belgian law provides that members of Eurojust may participate in the execution of investigative measures of judicial inquiry upon approval of the director 3 ; Irish legislation provides that Eurojust gives advice teams ${ }^{4}$; Lithuanian legislation provides that Eurojust should be informed in case of ascertainment of problems ${ }^{5}$.

\subsection{The legal framework of Eurojust}

In addition to these opportunities Eurojust can support JIT, based on its legal framework. Since it has legal personality may conclude agreements which contain and Joint Investigation Teams. Eurojust can support JIT based from its coordinating role:

- Eurojust may assist in identifying the issues that can create a team, through its coordination work. This has happened in the past and is likely to happen in the future. For example, a country may request Eurojust to assist in coordinating a cross-border issue and may result in the coordination the establishment of a Joint Investigation Team will serve investigation;

- Eurojust Decision provides Eurojust opportunity to ask the competent national authorities, to consider the creation of a team, or acting through its members (Article 6) or through college (Article 7). According to Article 6 members may ask the competent authorities to consider creating a team, it is a right of Eurojust to request Member States to reflect the possibility of creating a team in a particular case. Section 7 provides a greater competence: college may request the competent authorities establish a team. In this case, the authorities must give their reasons if they decide otherwise ${ }^{6}$.

- Eurojust can support negotiations for agreements on Joint Investigation Teams. Eurojust has legal expertise regarding the various national legal systems, and has experience in coordinating issues therefore can help with the legal aspects of the creation of the team, for example in relation to the scope of the agreement which is important for the acceptability of the information collected as a proof;

- Eurojust may assist in the operation of the team, for example, when it is necessary for methods of information gathering;

- Eurojust provides facilities for meetings 7. It provides the necessary technical equipment for secure communication and in some cases covers travel and accommodation expenses.

- Eurojust can follow the team work and to respond for its functionality. In particular, can provide national

\footnotetext{
${ }^{3}$ Article 9 (3) of the Law of 9 December 2004 relating to the International Mutual Assistance in Criminal Matters

${ }^{4}$ Section 9 (1) and (2), the Act on Criminal Justice (Joint Investigation Teams) 2004

${ }^{5}$ Article III Section 7, Article IV, Section 11, and Article VII, Section 31, the "Recommendation for the establishment and functioning of the International Joint Investigation Teams" approved by the General Prosecutor of the Republic of Lithuania by order dated December 21,2004

${ }^{6}$ Neni 8 i Vendimit të Eurojust

${ }^{7}$ Neni $7(g)$ i Vendimit të Eurojust
} 
observance of procedural requirements to collect evidence in order, then the evidence used in trial.

- Eurojust may also assist with the involvement of other countries not participating. Based on workload, can judge if other countries deal with related issues and if their involvement would be beneficial. Can help those countries that receive aid from Member States other than those established team and to establish contacts with the competent authorities of other countries8;

- Eurojust (along with EUROPOL) plays a key role in supporting the network of national experts to the Joint Investigation Team that was created in 20059. For this purpose have organized two meetings with experts to exchange experiences. Guide which contains legislation of the Member States, for Joint Investigation Teams, is gathered and distributed in November 2006. Eurojust presents on its website information to raise awareness about the Joint Investigation Teams in general and about the network of national experts in these particular teams and operational guidelines for the establishment of Joint Investigation Teams

In conclusion Eurojust and the Joint Investigation Teams aimed better coordination of the investigation of transnational crime issues. So far, the experience with JIT has been limited, due to the late implementation of this instrument but also because of the legal and practical difficulties associated with the creation and operation of the JIT. However, several initiatives are underway aimed at encouraging the creation of JIT. The role of Eurojust, should be seen in this context: his expertise in cross-border cooperation especially in the coordination of operational issues his international contacts and provides facilities-all of which serve to make a key player in assisting the Member States to overcome these difficulties and greater use of this new instrument of the European Union

\section{JIT Practical Cases with Eurojust and Europol}

The most recent case of the creation of a JIT was reported recently in a joint press release, between Europol and Eurojust judicial and police authorities of the four countries: France, Bulgaria, Poland and Belgium, successfully conducted a joint operation, supported and coordinated by Europol and Eurojust, against a criminal network of human trafficking operating in several Member States. The investigation began in October 2010 in France by the interregional judicial police of Lyon along with central police agency in the fight against trafficking (OCRTEH) under the supervision of the intraregional Lion court for ganized crime. Operation related to procurement and human trafficking of Bulgarian citizens. Young girls were recruited in Bulgaria for sexual exploitation in several European countries including Belgium and France. Earnings gathered from those who provide girls transferred via Western Union and invested in Bulgaria. A joint investigation team co-funded by Eurojust was established between Bulgaria and France, with the participation of Europol to handle this organized criminal group, but given the mobility of offenders, it was necessary to include Poland and Belgium in coordinated action.

To facilitate direct cooperation, the French police, took part in operations in Bulgaria, Belgium and Poland. Europine warrant six, four of them in action, and forwarded to the French authorities arrested nine people total. They raided 13 homes, and resulted in the seizure of more documentary evidence, and mobile phones. Coordination Centre was established in Eurojust, and directed by French counter Eurojust, with the help of Case Analysis Unit, who gave great support in the execution of the arrest warrant. The operation was supported every day by Europol teams of against human trafficking, and making available mobile office. The collected information, has been analyzed and exchanged in real time, the data collected was compared immediately, and identified unfamiliar connection with other investigations. This mode of action and interaction between agencies was to add value for the successful operation.

Another JIT was established between Bulgaria, Spain, Eurojust and Europol on a matter related to counterfeiting of the euro. JIT was supported by secret intelligence. As a result of this successful JIT were hit three groups that falsified the euro, and criminal organization involved in the production and distribution of the euro. During the investigation Europol prepared the intelligence reports and facilitated the exchange of information which resulted in the discovery of new criminal connections. Europol experts provided technical assistance and examined the premises where falsified euros that were in the center of Sofia, using special equipment to find traces of the euro. Europol also provided financial

\footnotetext{
${ }^{8}$ Eurojust has contact points in several other countries including: Turkey, Croatia, Liechtenstein, Norway, Switzerland, Iceland, the Western Balkan countries, USA, Canada, Russia, Ukraine, Macedonia, Israel, Japan, Singapore and in many American states South. Therefore, Eurojust may facilitate the provision of information, acquired not by member countries of the European Union.

${ }^{9}$ See "CATS - Joint Investigation Teams - Proposal for appointment of National Expert", Council Document 11037/05, 8 July 2005. This network is created continuously Hague Programme, section 2.3. its that stipulates that "in order to encourage the use of these joint investigative teams and exchanging experiences on best practices, each Member State shall designate a national expert" (Hague Programme, Annex I of the Conclusions of the European Council, 4 to 5 November 2004).
} 
support for the investigation. As a result of this international cooperation was arrested six people in Bulgaria, were seized counterfeit karmonedhat well as other documents including passports, credit cards, etc. Another JIT operation is performed for the criminal offense of falsification of the euro and documents, but this time in Poland. Europol, in this operation helped by facilitating international cooperation and identified banknotes distribution network outside Poland, and offered technical advice and equipment for discovery.

A meeting held at Eurojust led to the creation of a JIT between Belgium and France with the participation of Europol. French and Belgian investigators identify key players involved in taxes fraud, and the target was a Belgian company, which traded precious metals, which had clients in the UK, France and Spain. In this case, some member states, called for operational and analytical support from Europol to investigate, in relation to the taxes fraud. Europol's analytical findings showed a clear link between these countries. Europol took part in JIT, while France urged Europol mobile office, control and analyze the data gathered on the ground that, during the operation. EUROPOL expertise, analytical checks made to documents seized and identified connection with other investigations

\section{Conluzion}

Judicial and police cooperation in the European Union has gone through many changes since its creation. In this paper is presented the evolution of cooperation by focusing more on the legal aspect which begins with the Treaty on European Union and ends with the Treaty on the Functioning of the European Union. In a brief statement of changes brought treaties identify key developments related to the subject of the paper. Such is the creation of Eurojust in the Nice Treaty marks a milestone in the history of judicial cooperation in criminal matters.

Eurojust is an instrument of judicial cooperation in criminal matters established by the Treaty of Nice in 2001. Not only in the legal framework of the EU but also in the legal framework of Eurojust own keywords or duties of Eurojust are "facilitate coordination .... " , " provide support .... ". Eurojust is the EU agency that is most affected and the Treaty on the Functioning of the European Union, which provides for the creation of the EU Prosecutor, by Eurojust, thus strengthening the role of Eurojust and the burden this last, to support and strengthen coordination and cooperation between national authorities investigating and prosecuting, in connection with serious crimes, affecting two or more Member States or requiring the prosecution of offenses, based on common, based on the operations performed, and information provided by the authorities of the Member States, and by Europol .

European Prosecutor which is expected to be established by Eurojust aims to combat crimes affecting the financial interests of the European Union. Even though the prosecution will be created by Eurojust it differs from Eurojust because it replaces the national authorities in some competence and specific activity while the role of Eurojust continues to be coordination and support.

One of the specific tasks of Eurojust is mediation if the competent authorities have difficulty with performance requirements. The mission of Eurojust to promote coordination carried out under the statutory regime in the field of cooperation which is continuously developed since the Treaty of European Union set of EU competence in this field. Convention on Mutual Legal Assistance in 2000 is the cornerstone of this regime. Convention in the EU is the main mechanism for judicial assistance requests.

Convention on Mutual Legal Assistance in 2000, in Article 13, provides for the establishment of Joint Investigation Teams and along with JIT Framework Decision constitutes the legal framework for the establishment and functioning of these teams. Joint investigation teams are a new form of cooperation used less. Legal basis sets out in detail the main principles for the creation of JIT, JIT requirements to create, structure, function, and also running a JIT model agreement to be considered by the States before the creation of JIT.

While the advantages as team members are numerous and are mentioned below:

- as team members the opportunity to share information directly, without any formal request;

- to request investigative measures between team members, without the need for custom paper;

- opportunity for members to be present at interviews, house checks, etc. ., in all jurisdictions covered;

- opportunity to increase trust between professionals from different jurisdictions to work together and establish strategies for investigation and prosecution;

- possibility of coordinating efforts in the country and informal exchange of specialized knowledge;

- possibility of involvement of Europol and Eurojust to support and direct aid;

Difficulties seem to create JIT triumph given the small number of JIT that are set up now. However, it should be noted that all cases are created JIT have been successful and have made important progress in cooperation among states to combat crime effectively. 


\section{References}

Dokument i Këshillit 11037 105, 8 korrik 2005. “CATS - Ekipet e Përbashkëta Hetimore - Propozim për caktimin e ekspertëve Kombëtarë",

Akt i Këshillit i 29 majit 2000 që miraton në përputhje me nenin 34 të Traktatit për Bashkimin Europian Konventën për Ndihmën e Ndërsjellë në Çështje penale ndërmjet Shteteve Anëtare të Bashkimit Europian http://eur-lex.europa.eu/LexUriServ/site len/oj/2002//162/l_16220020620en00010003.pdf

Raportet vjetore të EUUROJUST 2007,http://EUROJUST.europa.eu/doclibrary/corporate/Pages/annual-reports.aspx

EuroJust Report 2010, http://eurojust.europa.eu/doclibrary/eurojust-framework/agreements/agreement\%20between\%20eurojust\%20and \%20europol\%20(2010)/eurojust-europol-2010-01-01-en.pdf

http://eurojust.europa.eu/doclibrary/corporate/eurojust\%20Annual\%20Reports/Annual\%20Report\%202012/Annual-Report-2012-EN.pdf https://www.EUROPOL.europa.eu/sites/default/files/council rec on jit agreement - march 2010.pdf

Official Journal of the European Communities 20.6.2002, (Acts adopted pursuant to Title VI of the Treaty on European Union) : Council Framework Decision of 13 June 2002 on joint investigation teams (2002/465/JHA). http://eur-lex.europa.eu/LexUriServ/site/en /oj/2002 /I_162//_16220020620en00010003.pdf

Programi i Hagës, 4-5 nëntor 2004.Aneksi I i Përfundimeve të Këshillit Europian,

Prokurori i Përgjithshëm i Republikës së Lituanisë, miratuar nga me urdhër datë 21 dhjetor 2004 "Rekomandim për krijimin dhe funksionimin e Ekipeve të Përbashkëta Hetimore Ndërkombëtare"

Rregullore e Punës së EUROJUST, miratuar nga Këshilli i EUROJUST në takimin e 30 majit 2002 dhe miratuar nga Këshilli në 13 qershor 2002

Vendim i Këshillit 2009/426/JHA i 16 dhjetorit 2008 për forcimin e EUROJUST dhe që ndryshon Vendimin 2002/187/JHA

Vendimi i Këshillit 2002/187/JHA i 28 shkurtit 2002 për krijimin e EUROJUST me qëllim forcimin e luftës kundër krimit të rëndë që i jep EUROJUST-it "si organ të Bashkimit" personalitet juridik

Vendimi i Këshillit 2003/659/JHA i 18 qershorit 2003 që ndryshon Vendimin 2002/187/JHA

Vendimi Kuadër i Këshillit i 13 qershorit 2002 për Ekipet e Përbashkëta Hetimore 
